\title{
The World Hope Index
}

\author{
Rahul S. Waslekar ${ }^{1 *}$
}

The main aim of the World Hope Index (WHI) is to help readers understand that hope can be perceived as a social product. This has been done through creating an index and quantifying Hope levels for 131 countries around the world for 2017. The paper also attempts to move the discourse of measuring human welfare and prosperity forward, from GDP growth rate and the Human Development Index to a new form of measure, being the World Hope Index. This is primarily because of the fact that the WHI takes into account change of income and thereby living conditions as a factor to measure hope, along with other economic and non-economic indicators. These indicators are divided into three parameters, namely, change, resources and stability. The indicators have been normalised on a range of $0-1$ using statistical techniques, followed by a geometric mean of all the indicators to arrive at a Hope Score for a particular country. The index rankings are supported with a comparative analysis of a sample set of countries. The paper concludes with a list of limitations and caveats.

\section{INTRODUCTION}

The main objective of the World Hope Index is to invoke the idea of hope as a social product at a time when the mainstream media is filled with the news of despair expressed in a growing incidence of terrorism, migration, and natural disasters. The discourse on hope over the past decades has primarily been at the individual and psychological level, as opposed to the state or societal level. This index would help this discourse to be shifted to the level of states and societies at large. The level of hope changes as a result of different behavioural changes within the society and thus turns out to be a product of a society at large. Hope being a social product has implications for a large number of people in a given community or even across different communities. Durkheim (1997) brought out the fact that hope can be a biological or social product. Different types of societies have different expectations of the future. For example, the people living in extreme climatic regions would hope for moderate weather. The people who live in a highly corrupt society would hope for corruption levels to decrease and transparency to increase. The people living in refugee camps would hope for prosperity and freedom.

On one hand, the delivery of hope as a social product can be achieved through change; on the other, a country can bring about change if there is hope. Adam Smith (2000), in An Inquiry into the Nature and Causes of the Wealth of Nation states, "the progressive

${ }^{1}$ R.D. \& S.H. National College, University of Mumbai, Smt. Jotu Kundnani Chowk, Linking Road, Bandra West, Mumbai, Maharashtra 400050, India

*To whom correspondence should be addressed: rahul.waslekar@gmail.com

Except where otherwise noted, this work is licensed under https://creativecommons.org/licenses/by/4.0

doi:10.22186/jyi.34.6.56-62 state is in reality the cheerful and the hearty state to all the different orders of the society. The stationary is dull; the declining, melancholy." It is only the progressive states that acquire its maximum potential. Thus, a country needs hope to create positive change, but it also needs change to create hope in the first place. Can hope be a cause or effect of positive change? After all, hope is always there within individuals, but it needs to be harnessed. In order to harness hope, it is necessary to understand and measure it.

A clear distinction must be brought out between hope and happiness as the two are often correlated with one another. According to Mayers (2007), "Happiness is life experience marked by a preponderance of positive emotion. Feelings of happiness and thoughts of satisfaction with life are two prime components of subjective well-being." From this we can understand that for happiness to occur at present, it is largely based on experiences and incidents that have taken place in the past. On the contrary, hope is the expectation of a positive future. Such positive future is a function of a country's progress in technology, innovation, and literacy among other factors.

\section{Definitions of Hope}

Hope is defined by scholars in different ways but broadly, it can be described as something positive that we wish would happen in the future. Normally, hope is considered in a personal context. This paper treats hope in a social context and questions if appropriate policies can deliver hope as a social product. Schumacher (2003) has pointed out six different characteristics of hope. Hope is accompanied by a minimum certitude and assurance with respect to the possible possession of the thing hoped for. Schumacher (2003) also characterises hope as something that is difficult to obtain; it is something that is not necessarily realised, but most importantly something that "consists in the attitude of expectant waiting." The phrase "expectant waiting" by itself implies that hope is something that can be attained in the future primarily on the basis of current circumstances.

However, it is Charles Snyder's contribution to this concept 
that has brought out a new definition which has been most common and analysed in recent times. Snyder (2002) defines hope as "the perceived capability to derive pathways to desired goals, and motivate oneself via agency thinking to use those pathways." In other words, hope involves both the "agency," which is the belief of bringing about change and targeting a certain goal and a "pathway," which involves various different ways of achieving the certain goal. This also goes to show that that hope is a complex and comprehensive concept.

An interesting analysis made by Boulding (1984) states: "[hope] rests on an optimistic image of the future which is perceived as having positive probability." By stating that hope is perceived as having a positive probability, Boulding implies that hope can be quantified. A positive probability ranges from 0 to 1 , thus making hope a quantifiable notion and not solely a highly qualitative or even psychological notion, but is felt at a much larger scale and perhaps by groups of people. This is once again similarly represented in Snyder's model of a "hope scale" that compares adult-measured hope and child-measured hope through a series of questions. Hence, gives further scope to create an index such as the World Hope Index.

Why the need for another index?

Today, it is possible to see how a country is fairing on almost any indicator. The indices that are currently available give us a good insight into the current and past performance of the countries. However, governments and societies have to plan for the future. What we need is an index that can help us use the data about the past to look ahead at future. After all, hope is about expectations for the future.

Development indices became known as the Human Development Index in the 1990s. Until then, the World Bank and others presented indices to measure economic a performance of countries. However, the Human Development Index captured the imagination of people. It suggested that development was not only about per capita income, but it was also about human life, which depended on income, health, and education. It was followed by many efforts to go beyond the concept of human development. The latest effort is to measure happiness in the form of various happiness indices. It is therefore important to understand the need for a World Hope Index and how it differentiates from other indices that are currently present.

1) To represent change - Any amount of change signifies progress.

2) Futuristic perspective - Even though the variables that have been chosen for this index provide data for the past or present, they have been chosen for their direct implications for the future rather than the present, which is what makes this index futuristic. For instance, savings rate is primarily for future purposes or even a high rate of innovation has a direct impact on future development of the given society.

3) Policy tool - The WHI as a policy tool would help countries better understand the level of hope on a comparative basis and help determine what policy mix will improve the prospects of hope.

4) Plurality of factors - Hope is a composite product of several variables and the WHI presents a composite index to help policy makers and researchers.

5) Even though the WHI is eventually a statistical representation of levels of hope in a country, it would better help spreading the message of hope in today's world, which appears in the media headlines filled with fear, despair and uncertainty. The index gives a message that hope is a public good that can be delivered with right mix of policies by governments and attitudes by people. A discourse focussed on the possibility of hope can help break the cycle of despair.

Difference between the World Hope Index and the World Happinness Index

The World Happiness Report published by the United Nations Sustainable Development Solutions Network measures happiness for 157 countries and was first published in 2012. As the prime aim of this index is to measure happiness, it is based on these six indicators: GDP per capita, social support, healthy life expectancy, generosity, freedom to make life choices, and perceptions of corruption. Most of the indicators are based on the Gallup World Poll survey, which surveys 1000 citizens from over 160 countries all over the world (GDP per capita and life expectancy are measured by the World Bank and the WHO, respectively). This index is based on social capital rather than financial or intellectual capital and hence it represents a limited perspective. As mentioned earlier, the World Hope Index is broad-based since hope is driven by comprehensive combinations of physical, intellectual, and social capital.

In addition, a limitation of the Happiness Index is that it is created on the basis of a survey method as opposed to the Hope Index, which uses national statistics collected by governments and development aid agencies.

\section{METHODS}

Collection of data was done through various online sources such as the World Bank open online database, CIA World Factbook, UNESCO Institute of Statistics, and other such open databases and reports. In total, there are three parameters which are further divided further into nine indicators. The three parameters are change, resources, and stability.

\section{Change}

Long term change in national income. Income is an essential factor in influencing the prospects of hopes and aspirations. It is proposed to use GDP in PPP terms to get a better reflection on local economies. Actual change and the rate of change both matter. Also, both the long term and short term change matter. This index includes actual change over ten years and the rate of change in the previous year. The best way to represent long term change is by taking the difference in GDP per capita over the last ten years (from 2005 to 2015 ) in actual income to measure the long-term change. Ten years is a good period as it is not too long or too short. Thus, this period of time seems most useful, though arbitrary, in this case. 
Short term rate of change in income. Short term changes are much more visible than long term changes which have structural impact on the prospects of hope. This was measured by using the growth rate in one year as compared to the previous year.

\section{Resources}

Innovation. Innovation is about finding new, effective and efficient solutions to complex problems and needs. It enhances creativity and an environment of striving for the better of the public and private. In addition, major changes in innovation can bring about a paradigm change. Agricultural revolution ten thousand years ago, industrial revolution over two centuries ago, and computer revolution in the last century demonstrate how innovation transforms life in the host geographies.

Investment in education. Education leads to productivity in the long run. That further creates economic and other choices, which deliver hope. A higher amount of public and private investment in education will empower a larger number of young people creating choices and therefore, hope for them. Moreover, higher investment improves the quality of education. As data for private and household investment in education is not available for most countries, this parameter will be measured by public expenditure in education.

Access to water and electricity. Access to water and electricity is essential for existence. Access to resources leads to fewer struggles for survival and creates scope for making efforts to realise hope. Not only is it beneficial on an individual level, but also helps large factories and industries function on a day-to-day basis. Availability of resources largely varies from access since it is only when one makes use of these resources in a fruitful way that there can be positive change.

Savings Rate. The purpose of saving is for it to be used in the future. A higher savings rate shows signs of better preparation for the future.

\section{Stability}

Migration (percentage of population emigrated). Here, the focus is on migration outwards/emigration. Migration is a direct representation of the absence of hope in a country. People migrate for various reasons - education, employment, safety, security, etc. Whatever the cause or the context, the underlying purpose is to look for high levels of hope overseas rather than in their home country. Emigration will be calculated as a Negative Hope factor in this index, as explained later.

Conflict and political stability. It is almost impossible for countries to have hope if there are continuous conflicts, violent crimes, and political instability as such factors only induce fear in a country. Several examples from the past and present situation in various countries show the breakdown of social fabric destroys hope. People are constantly under the fear of being displaced, lacking access to food and water, destruction of property, or even death in extreme cases.

\section{Indicators and Sources}

The WHI aims at creating a ranking of more than 100 countries, depending on the availability of comparative data. The following specific indicators were used in constructing the WHI.

Change:

1) Long term change in national income (from 2005 to 2015) -

GDP per capita (PPP) (World Bank Group [WBG], n.d.).

2) Short term change in income - GDP Growth (annual \%)

(WBG, n.d.).

3) Innovation (Dutta, Lanvin, \& Wunsch-Vincent, 2015). Resources:

4) Improved water source (\% of population with access) (WBG, n.d.).

5) Access to electricity ( $\%$ of population) (WBG, n.d.).

6) Investment in Education - Government expenditure on education, total (\% of GDP) (Central Intelligence Agency, n.d.;

WBG, n.d.)

7) Savings Rate - Gross Domestic Savings (\% of GDP) (WBG, n.d.).

Stability:

8) Migration - ( $\%$ of population emigrated) (United Nations Department of Economic and Social Affairs, 2015)

9) Political Stability and Absence of Violence (Kaufmann \& Kraay, n.d.)

After collecting and normalising all data, the geometric mean formula was used since geometric mean is normally used for considering different indicators (in inter-country comparison) to arrive at a single comparable figure for each country. The Human Development Index has used a geometric mean, which inspired the use of this device in constructing the World Hope Index. As compared to the arithmetic mean, geometric mean is considered to be more reliable as it moderates extreme values or fluctuations in a set of data. It is considered to be a precise figure taking into account all observations. Normalisation of figures was done through a few different methods as the type of data in subject to change.

In the case of static data, which includes most of the raw data in this index, the method of 'feature-scaling' has been implemented. Feature-scaling would bring all values for a particular indicator for all the countries into the range of $0-1$. The formula for the normalized score, $z_{i}$ is

$$
z_{i}=\frac{x_{i}-\min (x)}{\max (x)-\min (x)}
$$

where $\max (x)$ and $\min (x)$ are the maximum and minimum values of the range of the data available for the given indicator, and $x_{i}$ is the value of the specific country for the particular indicator.

The possibility of fear or presence of fear in any country would only result in a decrease in the amount of hope in any country. Hence, in order to make such indicators accountable for the World Hope Index, it is necessary to reverse the value for each country such an indicator that accounts for "Absence of Fear." In the case of the WHI, this occurs only with the case of migration as it indicates the absence of fear and not the presence. Therefore,

$$
z_{i}=1-\operatorname{val}(x)
$$

where $\operatorname{val}(x)$ is any given value of an indicator that accounts for 


\begin{tabular}{clc}
\hline Sr. no. & \multicolumn{1}{c}{ Indicator } & $\begin{array}{c}\text { Raw data } \\
\text { figure }\end{array}$ \\
\hline I. & $\begin{array}{l}\text { Long-term change in national income (from } \\
\text { 2005 to 2015) - GDP per capita, PPP (current } \\
\text { US\$) }\end{array}$ & $\begin{array}{c}2420.8- \\
1870.8= \\
\$ 550.00\end{array}$ \\
\hline II. & $\begin{array}{l}\text { Short-term changes in income - GDP per } \\
\text { capita growth (annual \%) }\end{array}$ & $6.48 \%$ \\
III. & $\begin{array}{l}\text { Savings Rate - Gross Domestic Savings (\% } \\
\text { of GDP) }\end{array}$ & $8.14 \%$ \\
IV. & Innovation & 30.95 \\
V. & Migration - (\% of population emigrated) & $3.73 \%$ \\
\hline VI. & $\begin{array}{l}\text { Improved water source (\% of population } \\
\text { with access) }\end{array}$ & $78.5 \%$ \\
\hline VII. & Access to electricity (\% of population) & $56.5 \%$ \\
\hline VIII. & Investment in education - government ex- & $7.2 \%$ \\
\hline IX. & penditure on education, total (\% of GDP) & \\
\hline
\end{tabular}

Table 1. Senegal raw data figures.

absence of fear and $z_{i}$ is the result. After normalising for all indicators, to arrive at the final "Hope Quotient," all the figures were averaged out using a geometrical mean. The formula for the same is

$$
W H I=\sqrt[x]{a_{1} \times a_{2} \times a_{3} \ldots a_{x}}
$$

where $a$ is the normalized value for each indicator. In other words, $a=z_{i}$ for each indicator. Thus, the Hope Quotient is finally expressed in a range between of $0-1$. This was followed by ranking countries in ascending order on the basis of the quotient.

Table 1 provides the example of how Hope Quotient for Senegal (selected at random) was calculated. In Table 1, data contained in rows I, II, III, V and VIII, the figures would need to be normalised using the feature-scaling method. However, in other cases, the method to normalise would be much more direct. Table 2 consists of all the normalised data that ranges from $0-1$ for Senegal. Once all the data is normalised for a particular country, the next and final step is to average all the values through using a geometric mean. Hence, the Hope Quotient for Senegal is WHI $=0.48$.

\section{RESULTS}

Applying the method explained in the case of Senegal in Tables 1 and 2, World Hope Index was created for 131 countries for 2017. Later on, all the countries were ranked. The ranking along with the Hope Quotient is presented as the final result in Table 3.

Certain common traits can be found in the top 25 countries. More than $90 \%$ of the population have accessibility to basic resources such as electricity and water, have seen a significant increase in GDP over 10 years, have strong emphasis on innovation and most are very politically stable.

Similarly, there are common features among the bottom 25 countries. Most of these countries have high rates of outwards migration, low on innovation, low accessibility of vital resources and have a relatively low increase in GDP per capita.

Even among the countries which are apparently similar in many respects including standard of living, have considerable differences in their rankings. Ireland ranks 1 and France ranks 25. We will discuss this below with the example of Ireland and France.

An anomaly in this index is the low ranking of United Arab Emirates (UAE). The prime reason for this is that while almost most countries increased their per capita income in the past ten years, UAE's GDP per capita decreased significantly. On the other hand, UAE is known as a destination of hope where Asian labourers go to work in the construction sector and businessmen shift to take advantage of the liberal tax regime and the ease of doing business. The UAE government focuses on the future and even has a Minister for Future. In a cabinet reshuffle that took place in October 2017, young professionals in their twenties and early thirties were appointed as ministers in charge of advanced sciences, knowledge creation, artificial intelligence, and youth empowerment. There are clear plans to craft a future full of hope that can equate UAE with the most advanced segments of the American scientific community, including an aspiration for landing a man on Mars. With a strong emphasis on knowledge, science, and an open trading environment, UAE offers hope. However, these facts are not reflected in the index as they are specific to that country. It is necessary to undertake research in future to examine how such specific exceptionalism has an impact on the potential delivery of hope in some countries.

\section{DISCUSSION}

Ireland has topped the World Hope Index 2017. One of the most noticeable reasons for this is the fact that Ireland reached a staggering growth rate of 26\% in 2015 (Coffey, 2016), which goes to show that it is the rapid change in the short run that has really given a big boost to Ireland's prosperity. From 2014 to 2015, Irish exports increased by almost $20 \%$, government spending dropped by $7 \%$, and capital investments increased by $28 \%$. However, it is not only the short-term change that has been beneficial, but change over a period of a much wider timespan that has helped them. It has been exactly 50 years since Ireland has provided free education to their citizens. It is believed that over one third (and less than half) "of Ireland's economic growth over the period 1990-2010 arose from the improving educational attainment of the labour force" (FitzGerald, 2017).

Taking the argument forward, from 1990 to 2005, employment increased from 1.1 million to 1.9 million, which led to a major increase in standard of living for citizens. Also, in the field of agriculture, there has been a decrease in labour force from $25 \%$ in the early 1970 s to just $5 \%$ in 2009 . This is due to new opportunities in various other sectors that rose over the same time span. The country's openness to global markets has helped the country soar up high over the past 25 years and is now a highly attractive place for people from around the globe to settle and make a living.

However, if we compare Ireland to any other country in the region, taking France for instance (ranked at 25), the differences 


\begin{tabular}{|c|c|c|}
\hline Sr. no. & Indicator & $\begin{array}{l}\text { Raw data } \\
\text { figure }\end{array}$ \\
\hline I. & $\begin{array}{l}\text { Long-term change in national income } \\
\text { (from } 2005 \text { to 2015) - GDP per capita, } \\
\text { PPP (current US\$) }\end{array}$ & 0.271 \\
\hline II. & $\begin{array}{l}\text { Short-term changes in income - GDP } \\
\text { per capita growth (annual \%) }\end{array}$ & 0.636 \\
\hline III. & $\begin{array}{l}\text { Savings Rate - Gross Domestic Savings } \\
(\% \text { of GDP) }\end{array}$ & 0.472 \\
\hline IV. & Innovation & 0.3095 \\
\hline V. & $\begin{array}{l}\text { Migration - ( } \% \text { of population emi- } \\
\text { grated) }\end{array}$ & 0.924 \\
\hline VI. & $\begin{array}{l}\text { Improved water source ( } \% \text { of popula- } \\
\text { tion with access) }\end{array}$ & 0.785 \\
\hline VII. & Access to electricity ( $\%$ of population) & 0.565 \\
\hline VIII. & $\begin{array}{l}\text { Investment in education - government } \\
\text { expenditure on education, total }(\% \text { of } \\
\text { GDP) }\end{array}$ & 0.553 \\
\hline IX. & $\begin{array}{l}\text { Political stability and absence of } \\
\text { violence }\end{array}$ & 0.4 \\
\hline
\end{tabular}

Table 2. Senegal normalised data figures.

are noticeable. Before understanding why the two countries differ, we must note that several similarities do exist. The two of them are active members of the European Union, they both are capital intensive countries, and are highly innovative on several fronts. Also, France and Ireland both have contributed to the world majorly in terms of philosophy, automobiles, and even science. Additionally, both France and Ireland have a GDP (PPP) of over $\$ 40,000$. Despite this, why is there a disparity in the level of hope? The change in GDP (over 10 years) of Ireland is three times that of France, which is a very influential indicator. Also, Ireland is also more politically stable than France, giving it the upper edge. Unemployment has always been an issue in France over the past decades and each passing government has tried to deal with this major challenge. Youth unemployment rate is at $23.7 \%$ and "the last time the growth rate surpassed the 3 percent mark was 17 years ago" (Stephens, 2017). Moreover, an increase in terrorist attacks in the recent few years has acted as a dominant factor for hope levels to decrease. While France is similar to Ireland on many fronts, it lacks in many other aspects. The World Hope Index has created some dilemmas which need to be addressed in future research.

\section{Dilemma for accounting change}

As mentioned earlier, it is the change over a certain period of time that represents significant shifts in levels of hope (either positive or negative). However, measuring change brings up a dilemma.

In 2005, the GDP per capita, (PPP) for Sri Lanka was $\$ 5,800$ and then increased to $\$ 11,700$ by 2015 . The difference between the two years is just under $\$ 6,000$, which corresponds to a change of over $100 \%$. For Austria, there has been an increase from $\$ 34,800$ to $\$ 49,400$ over the same ten-year span. This indicates an increase of over $\$ 14,500$, which corresponds to a change of $41 \%$. Thus, the rate of change in income in Austria is fairly lower than that of Sri Lanka. Although, the actual change in income is rather massive. Nevertheless, an average Austrian may be more hopeful than an average Sri Lankan, as the Austrian would have more opportunities and choices for education, employment and even entertainment. However, in the ultimate analysis, the reality is that Austria has stronger fundamentals while Sri Lankan has better rate of change. Hence, the WHI accounts for absolute change and not relative change, as relative change is not as credible. This dilemma is being addressed by considering actual change over a long period of time and the rate of change in the short run.

\section{Dilemma about survey method}

It is important to bring up the point of why this index has been created on the basis of already existing statistics and data rather than the survey method. The first imperfection with a survey is that it accounts for the opinions of only a few thousand people in a large country. This number is usually insignificant as opinions of millions of people have not been voiced.

Moreover, only a certain type of people might participate in such surveys. For example, people who live in more urban areas and are better off tend to participate in these surveys as it is easier for the surveyors to reach them. People who live far away from cities are difficult to reach and their opinions never get accounted for. Also, literacy, age, and many other factors may affect the opinion of the respondents.

An example of this is the Gallup World Poll, which conducts surveys upon which the World Happiness Index is based on the surveys conducted by the Gallup World Poll. The Gallup World Poll accounts for over 160 countries but uses a sample of only 1000 citizens per country which is once again a very limited number sample size to measure the happiness of an entire country. Perhaps, survey method can work in small and homogenous countries like those in Europe with a few million population. However, to say that a sample of 1000 persons can reflect the situation in China with its population of about 1.4 billion or Indonesia with a population of about 250 million, is not very credible.

\section{Future Research Needs}

The World Hope Index as presented here has merit on its own. However, further research is required to examine how it relates to the broader global discourse on the Sustainable Development Goals (SDGs) as well as national initiatives on innovation and the empowerment of youth and women in some countries.

It will be also useful to create the index on a regular periodical basis over a span of many years. The question of defining periodicity needs further thinking, but perhaps every two or three years could be appropriate, rather than on an annual basis, as it takes some time for change to have an impact. This would help to have a comparative analysis between countries and between years for any given country. Other indices such as the Human Development Index, Global Competitiveness Index, Corruption Perception Index, and several others have proved to be valuable for their comparative perspective offered over a long period. The same observation 


\begin{tabular}{|c|c|c|}
\hline Rank & Country & $\begin{array}{c}\text { Hope } \\
\text { Quotient }\end{array}$ \\
\hline 1 & Ireland & 0.727 \\
\hline 2 & Luxembourg & 0.721 \\
\hline 3 & Switzerland & 0.717 \\
\hline 4 & Sweden & 0.714 \\
\hline 5 & Denmark & 0.698 \\
\hline 6 & Norway & 0.696 \\
\hline 7 & Singapore & 0.691 \\
\hline 8 & Iceland & 0.687 \\
\hline 9 & Finland & 0.679 \\
\hline 10 & Netherlands & 0.676 \\
\hline 11 & Austria & 0.667 \\
\hline 12 & New Zealand & 0.666 \\
\hline 13 & Qatar & 0.664 \\
\hline 14 & Australia & 0.661 \\
\hline 15 & Germany & 0.656 \\
\hline 16 & Canada & 0.653 \\
\hline 17 & United States & 0.651 \\
\hline 18 & Belgium & 0.643 \\
\hline 19 & United Kingdom & 0.643 \\
\hline 20 & Czech Republic & 0.636 \\
\hline 21 & Malta & 0.635 \\
\hline 22 & Slovenia & 0.630 \\
\hline 23 & Korea, Rep. & 0.626 \\
\hline 24 & Japan & 0.626 \\
\hline 25 & France & 0.624 \\
\hline 26 & Estonia & 0.621 \\
\hline 27 & Slovak Republic & 0.613 \\
\hline 28 & Malaysia & 0.610 \\
\hline 29 & Poland & 0.602 \\
\hline 30 & Hungary & 0.600 \\
\hline 31 & Spain & 0.597 \\
\hline 32 & Chile & 0.589 \\
\hline 33 & Latvia & 0.588 \\
\hline 34 & Portugal & 0.586 \\
\hline 35 & Lithuania & 0.585 \\
\hline 36 & Oman & 0.582 \\
\hline 37 & Mauritius & 0.581 \\
\hline 38 & Italy & 0.580 \\
\hline 39 & Uruguay & 0.573 \\
\hline 40 & Saudi Arabia & 0.573 \\
\hline 41 & Vietnam & 0.571 \\
\hline 42 & Botswana & 0.569 \\
\hline 43 & Panama & 0.568 \\
\hline
\end{tabular}

\begin{tabular}{|c|c|c|}
\hline Rank & Country & $\begin{array}{c}\text { Hope } \\
\text { Quotient }\end{array}$ \\
\hline 44 & Bhutan & 0.564 \\
\hline 45 & Cyprus & 0.559 \\
\hline 46 & Seychelles & 0.558 \\
\hline 47 & Barbados & 0.557 \\
\hline 48 & Bulgaria & 0.555 \\
\hline 49 & Argentina & 0.548 \\
\hline 50 & Belarus & 0.544 \\
\hline 51 & Romania & 0.541 \\
\hline 52 & South Africa & 0.534 \\
\hline 53 & China & 0.531 \\
\hline 54 & Serbia & 0.529 \\
\hline 55 & Israel & 0.525 \\
\hline 56 & Brazil & 0.524 \\
\hline 57 & Paraguay & 0.516 \\
\hline 58 & Bolivia & 0.514 \\
\hline 59 & Namibia & 0.514 \\
\hline 60 & Morocco & 0.511 \\
\hline 61 & Greece & 0.506 \\
\hline 62 & Croatia & 0.503 \\
\hline 63 & Trinidad and Tobago & 0.502 \\
\hline 64 & Kazakhstan & 0.502 \\
\hline 65 & Peru & 0.499 \\
\hline 66 & Thailand & 0.499 \\
\hline 67 & Macedonia, FYR & 0.499 \\
\hline 68 & Moldova & 0.498 \\
\hline 69 & Mexico & 0.496 \\
\hline 70 & Ecuador & 0.494 \\
\hline 71 & Ghana & 0.494 \\
\hline 72 & Cote d'Ivoire & 0.490 \\
\hline 73 & Tunisia & 0.489 \\
\hline 74 & Russian Federation & 0.487 \\
\hline 75 & Sri Lanka & 0.485 \\
\hline 76 & Senegal & 0.484 \\
\hline 77 & Dominican Republic & 0.482 \\
\hline 78 & Indonesia & 0.481 \\
\hline 79 & Jordan & 0.481 \\
\hline 80 & Albania & 0.477 \\
\hline 81 & Turkey & 0.477 \\
\hline 82 & Colombia & 0.470 \\
\hline 83 & Bahrain & 0.469 \\
\hline 84 & India & 0.468 \\
\hline 85 & Armenia & 0.467 \\
\hline 86 & Fiji & 0.465 \\
\hline 87 & Honduras & 0.464 \\
\hline
\end{tabular}

\begin{tabular}{|c|c|c|}
\hline Rank & Country & $\begin{array}{c}\text { Hope } \\
\text { Quotient }\end{array}$ \\
\hline 88 & Jamaica & 0.463 \\
\hline 89 & Azerbaijan & 0.463 \\
\hline 90 & Nicaragua & 0.462 \\
\hline 91 & Georgia & 0.456 \\
\hline 92 & Iran, Islamic Rep. & 0.453 \\
\hline 93 & E1 Salvador & 0.453 \\
\hline 94 & Phillippines & 0.448 \\
\hline 95 & Algeria & 0.444 \\
\hline 96 & Tajikstan & 0.440 \\
\hline 97 & Guatemala & 0.433 \\
\hline 98 & Kyrgyz Republic & 0.428 \\
\hline 99 & Swaziland & 0.425 \\
\hline 100 & Rwanda & 0.421 \\
\hline 101 & Egypt, Arab Rep. & 0.420 \\
\hline 102 & Gambia, The & 0.414 \\
\hline 103 & Guyana & 0.405 \\
\hline 104 & Lebanon & 0.405 \\
\hline 105 & Zimbabwe & 0.401 \\
\hline 106 & Malawi & 0.400 \\
\hline 107 & Cameroon & 0.393 \\
\hline 108 & Mozambique & 0.392 \\
\hline 109 & Nepal & 0.390 \\
\hline 110 & Ukraine & 0.389 \\
\hline 111 & Angola & 0.386 \\
\hline 112 & Togo & 0.385 \\
\hline 113 & Tanzania & 0.375 \\
\hline 114 & Bangladesh & 0.374 \\
\hline 115 & Burkina Faso & 0.370 \\
\hline 116 & Kenya & 0.363 \\
\hline 117 & Ethiopia & 0.352 \\
\hline 118 & Nigeria & 0.351 \\
\hline 119 & Zambia & 0.346 \\
\hline 120 & Mali & 0.346 \\
\hline 121 & Uganda & 0.345 \\
\hline 122 & Niger & 0.345 \\
\hline 123 & Guinea & 0.341 \\
\hline 124 & Madagascar & 0.337 \\
\hline 125 & Venezuela, RB & 0.326 \\
\hline 126 & Myanmar & 0.324 \\
\hline 127 & Pakistan & 0.305 \\
\hline 128 & Sudan & 0.276 \\
\hline 129 & Burundi & 0.275 \\
\hline 130 & United Arab Emirates & 0.184 \\
\hline 131 & Yemen, Rep. & 0.084 \\
\hline
\end{tabular}

Table 3. World Hope Index 2017 Rankings and Hope Quotient. 
can be made about the World Hope Index.

\section{CONCLUSION}

If we treat hope as a social product, it is important to examine factors beyond human development - health, education, and income. Other drivers such as political stability, innovation and resources play key role in delivering hope. The index also represents how change in the long run, as well as short run acts as an influential factor while measuring for hope and prosperity of a country. Also, in the WHI we can see the existence of many non-OECD members in the top 50 rankings as it is not the case with the HDI and other indices as well while countries in the bottom quarter remain nearly the same. Thus, in order to have hope, it is necessary to go beyond income, health and education, but without good income, health and education, a country cannot have either hope, happiness or human development and find itself in the bottom quarter of any index.

The World Hope Index is an effort to change discourse from despair to hope, from happiness about past achievements to expectations of future outcomes, from hope as an individual sentiment to hope as a social product, from static data to an emphasis on change and from survey methods generally used to measure hope to the use of macro data to determine policy priorities for delivering hope.

Such an effort to shift the terms of discourse can by no means be perfect. At the minimum level to have the world talk about hope rather than bad news on television channels and to look at hope as something that can be made possible through policy priorities would be a small beginning in this direction. The research community can sharpen the tools or propose alternative tools, taking off from this modest effort. But every new direction needs a beginning and that is what is offered here.

\section{ACKNOWLEDGEMENTS}

The author is grateful to Dr. Shiva Makki (The World Bank, Washington D.C.) and Prof. Satish Deodhar (Indian Institute of Management, Ahmedabad) for guiding and advising him in improvising several earlier drafts of this paper.

\section{REFERENCES}

Boulding, K. (1984). Sources of Reasonable Hope for the Future, American Economic Review, 74(2), 221-25.

Central Intelligence Agency. (n.d.). The World Factbook, Education expenditures. Retrieved from https:/www.cia.gov/Library/publications/the-world-factbook/rankorder/2206rank.html

Coffey, A. S. (2016). Economy expands by $26.3 \%$, The Irish Economy. Retrieved from http:/www.irisheconomy.ie/index.php/2016/07/12/economy-expands-by-26-3/

Durkheim, E. (1997). The Division of Labor in Society. New York, NY: Free Press.

Dutta, S., Lanvin, B., \& Wunsch-Vincent, S. (2015). The global innovation index 2015: Effective innovation policies for development. Geneva: WIPO

FitzGerald, J. (2017). In Ireland, free education has more than proved its worth. The Irish Times. Retrieved from https://www.irishtimes.- com/business/economy/in-ireland-free-education-has-more-thanproved-its-worth-1.3022196

Gallup and Operation Hope. (2013). The 2013 Gallup-Hope Index. Retrieved from www.gallup.com/file/services/176750/2013\%20Gallup\%20HOPE\%20Report.pdf

Helliwell, John F., Richard, L., \& Sachs, J. (2015). World Happiness Report 2015. New York: Sustainable Development Solutions Network.

Institute for Economics and Peace. (2015). Global Peace Index 2015: Measuring Peace, its causes and its economic value. Sydney: Institute for Economics and Peace.

Kaufmann, D., \& Kraay, A. (n.d.). Political Stability and Absence of Violence. The World Bank Group, The Worldwide Governance Indicators (WGI) project. Retrieved from http://info.worldbank.org/governance/wgi/index.aspx\#home

Myers, D. (2007). Psychology of happiness. Scholarpedia, 2(8), 3149. doi:10.4249/scholarpedia.3149

Schumacher, B. N. (2003). A philosophy of hope Josef Pieper and the contemporary debate on hope. New York: Fordham University Press.

Smith, A., \& Cannan, E. (2000). The Wealth of Nations. New York: Modern Library.

Snyder, C. R. (2002). Hope Theory: Rainbows in the Mind. Psychological Inquiry, 13(4), 249-275. doi:10.1207/s15327965pli1304_01

Stephens, B. (2017). What Has Failed in France. New York Times. Retrieved from https://mobile.nytimes.com/2017/05/05/opinion/whathas-failed-in-france.html

The United Nations Development Programme. (2015). Human Develop ment Index (HDI) | Human Development Reports. Retrieved from http:/hdr.undp.org/sites/default/files/2015_human_development_report.pdf

United Nations Department of Economic and Social Affairs. (2015). Trends in International Migrant Stock: The 2015 Revision. (United Nations database, POP/DB/MIG/Stock/Rev.2015)

World Bank Group. (n.d.). Access to electricity (\% of population). Retrieved from http://data.worldbank.org/indicator/EG.ELC.ACCS.ZS

World Bank Group. (n.d.). GDP per capita (current US\$). Retrieved from http://data.worldbank.org/indicator/NY.GDP.PCAP.CD?view=chart

World Bank Group. (n.d.). GDP per capita growth (annual \%). Retrieved from http://data.worldbank.org/indicator/NY.GDP.PCAP.KD.ZG? view $=$ chart

World Bank Group. (n.d.). Government expenditure on education, total (\% of GDP). Retrieved from http://data.worldbank.org/indicator/SE.XPD.TOTL.GD.ZS

World Bank Group. (n.d.). Gross domestic savings (\% of GDP). Retrieved from http://data.worldbank.org/indicator/NY.GDS.TOTL.ZS

World Bank Group. (n.d.). Improved water source (\% of population with access). Retrieved from http://data.worldbank.org/indicator/SH.H2O.SAFE.ZS?view=chart 